\title{
A PEDAGÓGUSOK SZAKMAI ÖNÉRTÉKELÉSE ÉS SZAKMAI ÉNHATÉKONYSÁGUK FORRÁSAI
}

\author{
ZAGYVÁNÉ SZÜCS IDA \\ Eszterházy Károly Egyetem \\ Neveléstudományi Intézet
}

Tanulmányunk egy beágyazott kutatás harmadik, kvalitatív szakaszának eredményeit ismerteti. A vizsgálat fó fókusza a pedagógusok szakmai önértékelése és szakmai énhatékonyságának forrásai. Eredményeink alapján elmondható, hogy sajátos mintázatok rajzolódnak ki a szakmai önértékelés alacsony/magas és a szakmai énhatékonyság domináns forrásai szempontjából. A pedagógusok szakmai önértékelését meghatározó saját elvárásokban megjelenik a külső értékelés (minősítés) elvárásrendszere, de nem játszik meghatározó szerepet. A külső értékelés eredményével nem elégedett pedagógusok nézeteinek feltárása révén értékes ismeretekhez jutottunk a külső értékelés és az önértékelés eltérésének okaival kapcsolatban, amelynek alapján további fejlesztési célokat határozhatunk meg az életpályamodell és a pedagógusok önértékelési kompetenciáinak fejlesztésére vonatkozóan.

\section{Bevezetés}

A pedagógusok előmeneteli rendszerének bevezetése, amely egyszerre tűzte ki célul a pedagógusok minősítését és szakmai fejlődésének támogatását, vezetett bennünket annak kiderítésére, hogy hogyan értelmezik a pedagógusok a szakmai önértékelés fogalmát, milyen tényezők befolyásolják azt, és hogy mindez hogyan segíti a pedagógusok szakmai fejlődését. Egy a közelmúltban lezajlott beágyazott kutatásunk során (Creswell és Plano, 2007) két nagy terület elemzésére vállalkoztunk: a pedagógusok minősítése mint külső értékelés, valamint a pedagógusok szakmai énhatékonyságának személyes észlelése és a szakmai önértékelés kapcsolódási pontjainak a feltárása. A vizsgálat három szakaszból épült fel. Jelen tanulmányunkban a harmadik szakasz bemutatására vállalkozunk, amelyet a kvalitatív paradigma jegyében készítettünk el. Mintánkat a beágyazott kutatás második (kvantitatív) vizsgálati szakaszának mintájából választottuk ki azzal a céllal, hogy mélyfúrásokat végezzünk, egyéni nézeteket tárjunk fel. Kutatási célként fogalmaztuk meg annak kiderítését, hogy a konkrét szakmai környezet mennyiben befolyásolja a pedagógusok önmaguk számára megfogalmazott szakmai elvárásainak körét, beazonosíthatók-e nézeteikben 
a szakmai énhatékonyság észlelésének a kvantitatív kutatás során detektált forrásai, és ha van eltérés a pedagógusok szakmai önértékelése és a külső értékelése (minősítés) között, akkor mi lehet annak az oka.

\section{Elméleti alapozás}

Beágyazott kutatásunk elméletei kereteit az önszabályozó tanulásnak, az önértékelésnek, a pedagógusok szakmai önértékelésének és a szakmai énhatékonyság észlelésének a fogalmi bázisára alapozva fektettük le. Az önszabályozó tanulás volt számunkra a kiindulópont, amelyen belül az önértékelés mint állandó folyamat biztosítja a tanuló (itt most a tanuló pedagógust értjük) adaptivitását, fejlődését. Az önszabályozó tanulás különböző modelljeit (Winne és Hadwin,1998; Zimmerman, 2000; Pintrich, 2000; Boekaerts, 2011; Efklides, 2011; Järvelä és Hadwin, 2013) vizsgálva megállapíthatjuk, hogy az önszabályozás egy aktív, konstruktív folyamat. A szabályozás jelenti a célkitűzést, a monitorozást, a megismerés kontrollálását, a motiváció és viselkedés összhangba hozatalát a külső, környezeti és belső elvárásokkal, lehetőségekkel. Ezek a cselekedetek állandó összeköttetést biztosítanak az egyén és a kontextus, illetve az elért teljesítményük között. A pedagógust most mint tanulót azonosítjuk a szakmai fejlődés (tanulás) során. Ehhez elengedhetetlen az önértékelés (Guskey, 2002; MacGilchrist, Myers és Reed, 2004; Harris és Brown, 2009; Zheng 2009; Yeung, Craven és Kaur, 2014), ami szorosan összekapcsolódik az önreflexióval (self-assessment), és nem mást jelent a fogalom, mint az egyén saját tanulására vonatkozó értékítéletét (self-evaluation), amelynek következtében születik meg az önmegelégedés vagy elégedetlenség, illetve azt követően az adaptív vagy defenzív magatartás. Az önreflexió és önértékelés együttléte biztosítja a rendszer korrekcióját, új kihívásokhoz való alkalmazkodását. A megfelelő önismeret és reális önértékelés segíti a pedagógust szakmai arcképének megrajzolásában, identitásának definiálásában. A szakirodalom feltárása során felmerült, lévén a személyiségről van szó, az én (self) fogalmának szerepe. A pszichológiai megközelítésből kiindulva jutottunk el a szociális tanuláselmélet énkép-definíciójához (Bandura, 1977, 1986; Athanasou, 2005), amely egy új dimenziót tárt elénk, ez pedig az énhatékonyság. Az énhatékonyság alakulását befolyásoló tényezők közül kiemelkednek a személyiségből adódó jegyek és az, hogy mások milyen visszacsatolásokat nyújtanak az egyén felé, azaz milyen a saját énhatékonyságának észlelése, de nem tekinthetünk el azon csoport kollektív hatékonyságától sem, amelynek ez az egyén a tagja (Bandura, 2001).

Az énhatékonyság fogalmán belül külön részterület a szakmai énhatékonyság. A pedagógusok szakmai énhatékonyságának észlelése nem értelmezhető motivációik, a szakmai életben elért eredményeik, azok mások által történő elismertsége, a munkájukkal való 
elégedettség érzése nélkül. A szakmai énhatékonyság észlelése ugyanakkor vissza is hat motivációikra és további teljesítményeikre (Caprara és mtsai., 2006). Ha a pedagógus erős szakmai énhatékonysággal rendelkezik, akkor az erősíti a szakma iránti elkötelezettségét, a szakmai közösséghez, a tanítványokhoz, szülőkhöz való kötődését, és ösztönzi őt arra, hogy minél hatékonyabb tanulási környezetet alakítson ki. Azok a pedagógusok, akik kételkednek saját szakmai énhatékonyságukban, a szakmai feladataik végrehajtásában való eredményességüket inkább annak feltételeként határozzák meg, hogy a feladataik végrehajtása során mennyiben segítette őt az iskola mint szervezet, a vezetők, kollégák, a tanulók és a szülők, vagyis az egész iskolára úgy tekintenek, mint a szakmai feladataik végrehajtását segítő komplex rendszerre (Caprara és mtsai., 2006).

Számtalan kutatásban vizsgálták meg a pedagógus szakmai énhatákonyságának észlelése és a tanulói eredményesség (Bandura, 1997; Caprara, 2002), a pedagógus szakmai elkötelezettségének és a pedagógus szakmájával való elégedettségének kapcsolatát (Caprara és mtsai., 2003a; Caprara és mtsai., 2003b). Mindezek a kutatások igazolták is, hogy a szakmai énhatékonyság észlelése, az előbb említett tanulói teljesítmény és a szakma iránti elköteleződés kölcsönösen erősítik egymást (Caprara és mtsai., 2006. 476.).

Mint már korábban utaltunk rá, tanulmányunk egy beágyazott kutatás szerves része, ezért fontosnak gondoljuk röviden összefoglalni, hogy milyen következtetések révén jutottunk el ezen újabb szakasz kutatási kérdéseihez.

A szakirodalom feltárását követően megvizsgáltuk, hogy maguk a pedagógusok milyen szakmai elvárásokat tartanak mérvadónak önmaguk számára, majd az eredmények alapján meghatároztuk a szakmai önértékelés fogalmát. A szakmai önértékelés jelenti a pedagógus szakmai tevékenységére vonatkozó értékítélet/értékítéletek folyamatos (periodikus) meghozatalát a pedagógus által, amely tudatos tevékenység. Az értékítéletet/értékítéleteket megelőzi a pedagógus tevékenységére történő reflektálás. Ez a reflektálás az önértékeléssel együtt megvalósul a hétköznapok szintjén, de kitágítható a pedagógus egész pályájára. A szakmai önértékelésnek három nagyon fontos jellemzőjét kell megemlítenünk. Az egyik, hogy elvárások (külső és belső) mentén történik. A belsőkben visszatükröződnek a külső elvárások, de megfogalmazódnak a pedagógus egyéni életútja által befolyásolt és létrehozott célok és törekvések is. A belső elvárások megfogalmazásához nélkülözhetetlen egy bizonyos szintű szakmai önismeret, amelynek elmélyülését segíti a szakmai tapasztalat. A külső elvárások esetében különösen fontosak az oktatást szabályozó különböző szintű dokumentumokban megfogalmazottak és a társadalom érdekeit visszatükrözőek. Ezek manifesztálódnak az oktatást szabályozó törvényekben, tantervekben és az adott iskola vagy intézmény működését szabályozó dokumentumokban. A külső elvárások közül kiemelkedően fontosak még a vezetők és a diákok elvárásai. A külső elvárásokhoz szorosan kötődik a külső értékelés, ha van. 
A szakmai önértékelésnél az értékítélet vagy értékítéletek meghozatalakor a második jellemző dolog, hogy a folyamat itt nem áll meg, hiszen a megalkotott értékítélet alapján a pedagógus különböző szakmai célokat fogalmaz meg önmaga számára. Ezek az elvárásokhoz való jobb igazodás érdekében, különböző fejlesztési módok aktív alkalmazása révén realizálódnak, vagyis az alkalmazkodás, az adaptivitás szolgálatában állnak. Harmadik tényezőkét pedig nagyon fontos megemlíteni azt az érzelmi beágyazottságot, amely a szakmai önértékelés esetében jól kimutatható, vagyis az érzelmek, a személyiség fejlődésének alapvető mozgatórugója. E fogalmi definíció tehát tükrözi, hogy a szakmai önértékelés a reflexióval együtt a pedagógus önszabályozó tanulásának és szakmai fejlődésének alapvető motorja (Zagyváné, 2019).

A fogalmi meghatározás lehetőséget teremtett számunkra egy kvantitatív nagymintás vizsgálat végrehajtására, amelyben egyértelműen kirajzolódott a saját elvárások és azokon belül is a pedagógus által követendőnek tartott személyiségtulajdonságok szerepe, illetve a reális önértékelés fontossága. Ideális esetben, reális önértékelésnél a külső és a saját elvárások lefedik egymást, nem ideális esetben eltérések lehetségesek. Számunkra fontos volt, hogy feltárjuk az egyéni nézeteket is ebben a kérdéskörben. Vizsgálatunk fó irányát az jelentette, hogy a szakmai kompetenciák egyéni leszűrődése mellett megjelenő egyéb elvárások (a külső értékelésen kívül) milyen mértékben játszanak szerepet a szakmai önértékelésben, és ezen belül a szakmai énhatékonyság forrásai milyen variációkban érhetők tetten az önértékelés során. Ezen célok mentén a kvantitatív dominanciájú vizsgálatra egy harmadik fázist, azaz egy kvalitatív elemzést építettünk.

\section{A kvalitatív kutatás bemutatása}

A kvalitatív tartalomelemzés során a következő kérdésekre kerestük a választ:

- Milyen mértékben határozza meg a pedagógus önmaga számára megfogalmazott elvárásait az a kontextus, amelyben dolgozik?

- Tetten érhetők-e az egyéni nézetekben az énhatékonyság észlelésének forrásai? Ha igen, milyen mintázatok formájában?

- A külső értékelés és a szakmai önértékelés eltérésének mik lehetnek az okai?

A fenti dilemmák tisztázására strukturált interjúkat készítettünk kilenc pedagógussal. Ezek mellett arra is megkértük a válaszadókat, hogy gondolattérképpel ábrázolják a szakmai önértékeléséről megfogalmazott nézeteiket. A gondolattérkép mellett azért döntöttünk, mert a viszonylag kevés számú interjúalanynak több lehetőséget kívántunk adni nézeteik megfogalmazására, kifejezésére, rendszerezésére. A gondolattérképek interjúalanyok általi értelmezését - csakúgy, mint az interjúkat - diktafonon rögzítettük, majd legépeltük. Ezek után kvalitatív tartalomelemzést végeztünk. 


\section{Minta és mintavétel}

Ebben a szakaszban a beágyazott kutatás ezt megelőző szakaszának mintájából történt meg az interjúalanyok kiválasztása. A mintavételi eljárásnak ezt a típusát minta-előstrukturálásnak nevezzük, amelynek célja, hogy az eseteket összehasonlítsuk meghatározott dimenziók mentén (Sántha, 2009. 93.). Kiindulásként a dimenziók a következők voltak: az előző szakasz eredményei alapján a pedagógusminősítés eredményével nem elégedett, magas/ pozitív és alacsony/negatív önértékelésü, valamint a szakmai énhatékonyság forrásainak két nagy köre alapján: a diák-(szülő) és kolléga-igazgató orientáltság. Az interjúk elkészítésekor nehézséget jelentett, hogy bár az előző kutatási szakaszban néhányan önkéntes alapon megadták az e-mail-címüket, mégis nehezen álltak rendelkezésre, amikor eljött a tényleges kikérdezés ideje. Itt elsősorban a külső értékelés eredményével nem elégedettekre gondolunk. Több esetben nem kaptunk visszajelzést a felkérö levelünkre, de olyan pedagógus is akadt, aki az utolsó pillanatban elállt az interjútól. Ezért végül úgy döntöttünk, hogy mintánkat kiterjesztjük, és megszólítottunk olyan pedagógusokat is, akik nem vettek még részt a minősítési eljárásban, illetve részt vettek, és elégedettek az ott elért eredményükkel, remélve, hogy információkat kapunk szakmai önértékelésükről az előbb említett dimenziók mentén. Az adatok felvételére 2018. június 14. és szeptember 30. között került sor.

\begin{tabular}{|c|c|c|c|c|c|c|}
\hline $\begin{array}{l}\text { interjú } \\
\text { alany }\end{array}$ & neme & $\begin{array}{l}\text { pályán } \\
\text { eltöltött év }\end{array}$ & fokozat & szak & iskola típus & település \\
\hline 1. eset & nő & 35 év & mestertanár & magyar-népművelés & gimnázium & város \\
\hline 2. eset & nő & 32 év & pedagógus I. & biológia-kémia & szakiskola & $\begin{array}{c}\text { megyei jogú } \\
\text { város }\end{array}$ \\
\hline 3. eset & nő & 20 év & pedagógus II. & $\begin{array}{l}\text { történelem-idegen } \\
\text { nyelv }\end{array}$ & gimnázium & város \\
\hline 4. eset & nő & 28 év & pedagógus II. & tanító & általános iskola & község \\
\hline 5. eset & nő & 1,5 év & gyakornok & $\begin{array}{l}\text { magyar-kommuni- } \\
\text { káció-mozgóképkul- } \\
\text { túra és média }\end{array}$ & szakgimnázium & város \\
\hline 6. eset & nő & 15 év & pedagógus II. & ének-idegen nyelv & szakgimnázium & $\begin{array}{l}\text { megyei jogú } \\
\text { város }\end{array}$ \\
\hline 7. eset & nő & 26 év & pedagógus II. & $\begin{array}{l}\text { matematika-infor- } \\
\text { matika-fizika }\end{array}$ & szakgimnázium & város \\
\hline 8. eset & nö & 28 év & pedagógus II. & $\begin{array}{c}\text { idegen } \\
\text { nyelv-történelem }\end{array}$ & gimnázium & $\begin{array}{l}\text { megyei jogú } \\
\text { város }\end{array}$ \\
\hline 9. eset & nő & 26 év & pedagógus II. & $\begin{array}{c}\text { idegen } \\
\text { nyelv-történelem }\end{array}$ & általános iskola & város \\
\hline
\end{tabular}

1. táblázat. A kvalitatív interjúk résztvevöi 
Mind a kilenc pedagógus nő volt. Szakmai tapasztalat alapján kettő kivételével húsz vagy annál több éve vannak a pályán (1. táblázat). Pedagógusfokozatok tekintetében a kutatótanár kivételével minden fokozat megjelent, de többségben voltak a pedagógus II. kategóriában lévők. Két pedagógus általános iskolában, a többiek középiskolában tanítanak. Településtípus vonatkozásában öten városban, ketten községben és ketten megyei jogú városban dolgoznak. Az interjúalanyok közül 7 fó vett részt minősítési eljárásban (1., 3. , 4., 6., 7., 8. és 9. esetek), és a kvantitatív kutatásunk alapján 3 fó nem volt elégedett az ott elért eredményével (4., 6. és 9. esetek).

\section{Kódolás}

A kvalitatív tartalomelemzést MAXQDA 12 elemző szoftverrel végeztük. Az elemzés első fázisában a legépelt szövegek kódolására került sor.

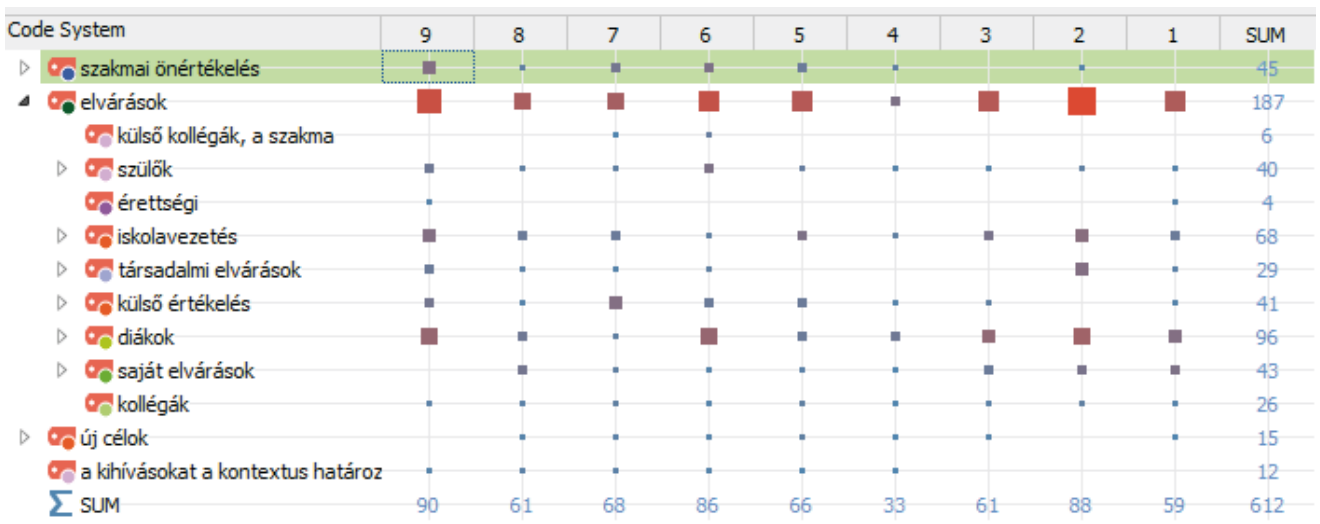

\section{1. ábra. A priori és a nyilt kódolás fó-és alkódjai}

Két logika, deduktív (priori) és induktív alapján végeztük a kódolást (1. ábra). A priori technika alapját az első, kvalitatív szakasz és a második, kvantitatív szakasz fó- és azok alkódjai adták (Sántha, 2009. 76.), amelyek a következők voltak:

szakmai önértékelés (főkód)

elvárások (fökód)

- szülök

- érettségi

- iskolavezetés

- külsó értékelés

- diákok

- kollégák

új célok (fókód) 
A három fő kategóriába nem illeszkedő szövegrészek kiesésének megakadályozása érdekében induktív logika mentén kódoltuk le azokat. Az így létrehozott új kódok:

önérvényesítés (főkód)

a kihivásokat a kontextus határozza meg (fókód)

Az elvárásoknál pedig két új alkódot hoztunk létre:

külsö kollégák és a szakma

saját elvárások

\begin{tabular}{|c|c|}
\hline esetek & Cohen-kappa értéke \\
\hline 1. eset & 0,96 \\
\hline 2. eset & 0,99 \\
\hline 3. eset & 0,97 \\
\hline 4. eset & 0,98 \\
\hline 5. eset & 0,98 \\
\hline 6. eset & 0,98 \\
\hline 7. eset & 0,95 \\
\hline 8. eset & 0,97 \\
\hline 9. eset & 0,98 \\
\hline
\end{tabular}

2. táblázat. A Cohen-kappa értéke az intrakódolás után

A magasabb megbízhatóság érdekében intrakódolást végeztünk, vagyis kétszer kódoltuk le a szövegeket, majd megbízhatósági mutatót számoltunk. A Cohen-kappa értékei a kódolás megbízhatóságát támasztották alá (2. táblázat).

13. A kvalitatív tartalomelemzés eredményei

\section{A kontextus szerepe}

Arra vonatkozóan, hogy az a közeg, ahol a pedagógus a munkáját végzi, mennyire befolyásolja saját elvárásainak a megfogalmazásában, nem tettünk fel kérdést, mégis a kilenc válaszadó közül hatan megemlítették.

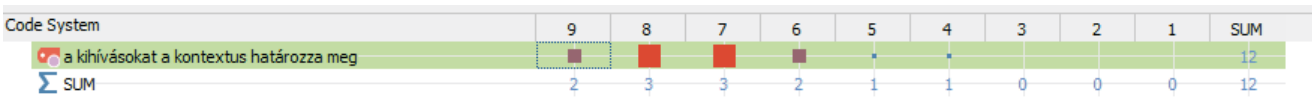

\section{2. ábra. A saját elvárásokat meghatározó kontextus szerepének megitélése}

A kontextus alatt több dolgot is értettek a pedagógusok (2. ábra). Egyrészt iskolatípust, azon belül évfolyamokat (nyolcosztályos gimnázium alsó évfolyamai vagy négyosztályos 
gimnázium tagozatos és fakultációs csoportjai), a diákok tudásszintjét, a szakot, vagyis hogy milyen tantárgyakat tanítanak, és a diákok neveltségi szintjét, amely nézeteik szerint erősen összefügg az iskolatípussal és a családi háttérrel.

... egy általános iskolában voltam, ez egy körzeti iskola volt, pici falvakból, ez 700-800 fót jelent. Úgy kell elképzelni, hogy második osztálytól nyolcadik osztályig általános angol nyelvoktatás. Aztán dolgoztam gimnázium és szakközépiskolában. Most jelenleg csak szintiszta gimnáziumi képzésben. Más a pedagógiai kihivás egy motivált, ambiciózus társasággal, más egy a szakmáját elötérbe helyezö tizenévessel (6. eset. 30.).

Visszamennék még a kezdötanári korszakomboz. Én akkor fóleg fizikát tanitottam. És fizikából például nagyon sok versenyeredményünk volt akkor. Nyolcosztályos gimnáziumban a kicsiket tanitottam kilencedikig. Ott nagyon sok versenyeredményünk volt, a mai napig megvannak az oklevelek. Én azt imádtam csinálni, fóleg kisérletezös versenyek voltak. Volt, ami nekem nagyon jól bejött. Szerettem, tehát nagyon sok versenyeredményünk volt. Az elmúlt tizenegy évben a középiskolában ott is volt versenyeredményünk. Ott a gyerek csípöböl kirázta. Ott más rendszerben versenyeztettünk, más kategóriában, mint a gimnazisták. Abhoz képest ök jók voltak. Nem tudtam felkésziteni öket, ahogy szerettem volna, és azt az eredményt nem tudtam belölük kihozni, amit szerettem volna (7. eset 8.).

Az elözö munkahelyemen a neveltségi szint az nagyon alacsony volt. Ott azért sok mindent meg kellett tanitani, a tisztálkodástól kezdve az öltözködésig minden, aztán még egyéb dolgokat is, ami úgy nagyon furcsa volt, hogy mi közöm nekem ehhez. Mert egy közösségben, ha valaki büdös, izzadtság szagú, akkor azt valahogy kezelni kell. Egy közösségben, ha valakinek nincsen pénze és nagyon szegény, akkor azt, hogy kezelik a közösség tagjai (7. eset 10.).

Nagyon nehéz szociokulturális háttérrel rendelkeznek a gyerekek. Minden kis elörelépés, ami akár az illemtanban, akár a viselkedésben, a higiéniában, a táplálkozásban, az életmódban pozitiv, elöremutató, kevesebbet hiányoznak, aktivabban részt vesznek bármilyen programban, vagy fel lehet az érdeklödésüket egy kicsit kelteni valami iránt, az már nekünk örömet okoz. Es ezt meg kellett nekünk is tanulni, illetve folyamatosan tanuljuk egymástól is a kollégákkal, hogy ezt valóban így értékeljék, mert ez nagyon nehéz. (4. eset 9.).

Lehet, hogy ezzel nem leszek népszerü, de az én lehetöségeim korlátozottak. Itt a mi tantestületünkben én ezt annyira nem tapasztalom, de egy évig egy másik városban tanitottam, és akkor mindjárt az elején kezdötanárként felfogtam, hogy attól függöen, hogy egy tanárnak milyen a végzettsége, milyen szakot tanit, nagyon nagy különbségek vannak. Akkor vezették be ezt a rendszert, hogy aki egyetemi végzettségü, több fizetést kap, mint aki föiskolai végzettségü. És ott a közgazdasági szakközépiskolában mondták a tanárok, hogy amikor ök végeztek, akkor ebböl nem lehetet egyetemi szakot csinálni. Ha akart volna sem tudott volna egyetemi végzettséget szerezni. Akkor miért legyen ö hátrányos? Teljesen igaza volt. Az, hogy ennyiféle szak van egy iskolában, mindegyik szaknak megvan a maga igaza, és nagyon sajnálom az igazgatóságot, 
hogy igazságot kell tenni közöttük, mert nem lehet. És éppen ezért én soha nem mérem magam másokhoz meg a mások versenyeredményéhez, mert tudom, hogy ha én indulok, akkor én mindig érek el és általában szép eredményt (8. eset 6.).

Úgy gondolom, hogy próbálom a koromat kihasználva motiválni a diákságot. Nehéz osztályokat kaptam, sok a viselkedészavaros, figyelemhiányos, SNI-s BTM-es diák. Tényleg sok, és a nehéz osztályokban is elértem, hogy egy félév-év alatt, hogy megszeressenek és hogy nem is a tantárgy iránti szeretet, de ha már engem tisztelnek és elfogadnak, akkor már könnyebben megy a tanítás (5. eset 15.).

..... ahhoz képest, hogy jó csoport vagy gyenge csoport van a kezem alatt (9. eset 42.)

A kontextus fontosságának az említése átvezetett bennünket a saját elvárásokhoz. Itt utalnunk kell az ezt megelőző kutatási szakaszra, amelynek eredményei azt támasztották alá, hogy a pedagógusok elsősorban a saját elvárásaiknak szeretnének megfelelni, valamint ezek nagy része az általuk fontosnak tartott személyiségtulajdonságok.

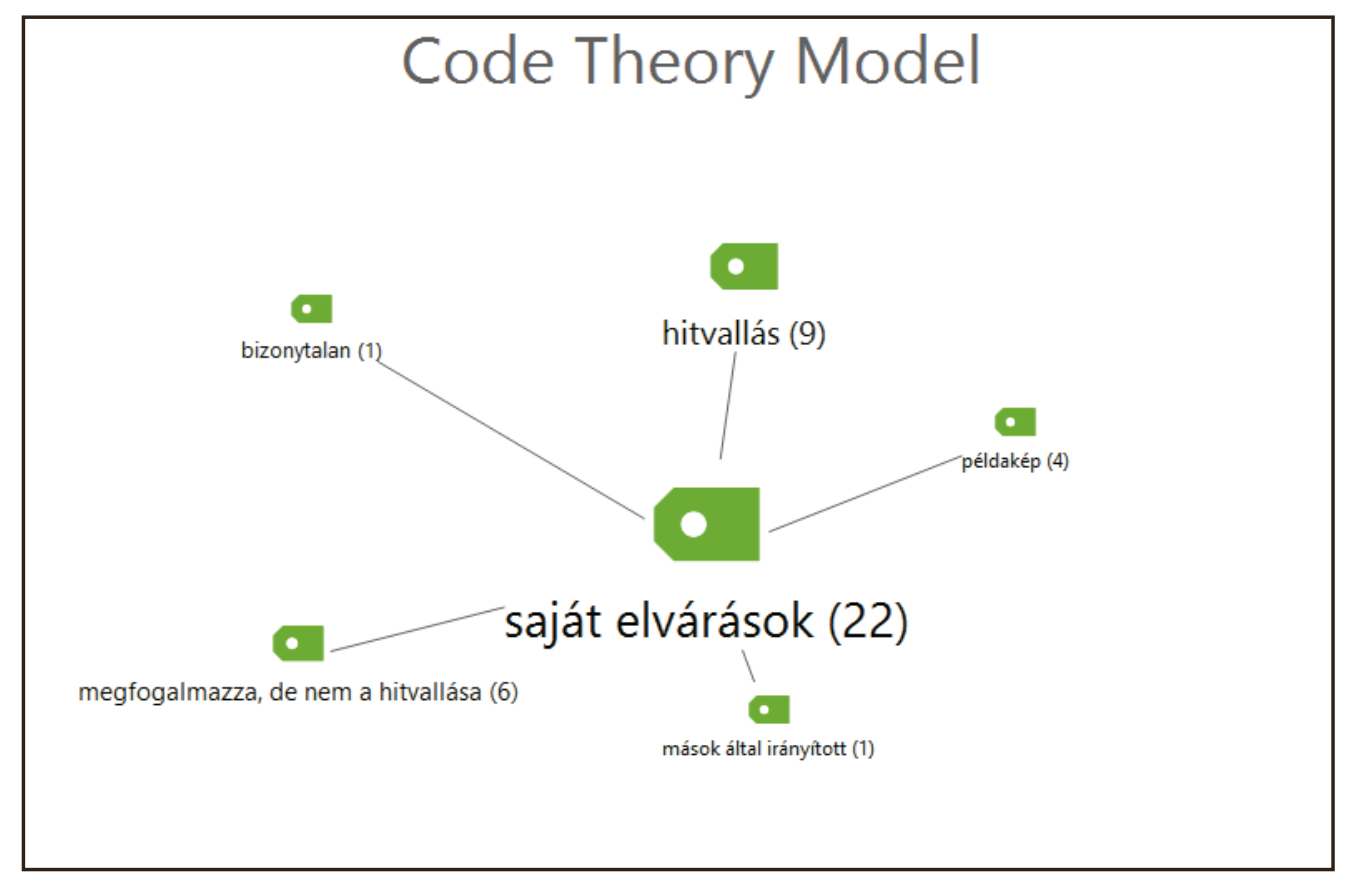

3. ábra. A saját elvárások alkódjai

A saját elvárások megfogalmazása többféleképpen történt. A 3. ábrán a kódok mellett a megemlítések száma látható. Öt pedagógus a szakmai hitvallását mondta el (1. 2. 3. 5 . és 7. esetek). 
A tiszta lelkiismeret, és hogy önmagunk céljainak és szándékainak feleljünk meg. A világnézetem az keresztény beállitottságú, és az a maximális erkölcsösséget jelenti, illetve azt, hogy a munkánkat mindig tökéletesen végezzük. Minden egyes pillanatban nagyon figyeljünk oda a másik emberre, hogy annak mik az érdekei, ugyanakkor a saját érdekeinket sem szabad alárendelni. Tehát a szeretet is sugározni kell, a tudást is. Szerintem úgy kell tanitani, hogy az irodalmi müveken keresztül, azok lényegén keresztül a személyiséget formáljam. Tehát az általam közvetitett érték interiozálódjon, vésödjön be, legyen a személynek a része. Én magam az éveken keresztül folyamatosan látom azt, hogy hogyan változik az emberségük a tanulóknak. Ha elkövet hibát, képes legyen bocsánatot kérni és változtatni például. Tehát ez egy óriási dolog, amikor beismeri valaki a hibáját, és képes ezen változtatni. Még nagyobb dolog, ha ezt teljes közösségben tapasztalom. (1. eset 6.).

Két pedagógus (2. és 8. eset) említette a hitvallás szükségességét, de nem fejtette ki.

... ha valakinek van egy belsö erös önértékelése, és tudja, hogy mit akar, és tudja, hogy ahhoz képest ö hol áll vagy mit csinál, ez egy pillér, de nem ... ettöl nem fogok összeomlani, és nem fogok kicsattanni, ez egy pillér egy visszacsatolás, de az én utamtól ne tud eltéríteni (3. eset 22.).

Három pedagógus esetében példaképek személyében nevezték meg a saját elvárásokat, úgy, mint saját szülők vagy pedagógusok.

... amikor én diák voltam, voltak olyan mintapedagógusok, akiket én szerettem volna követni a pályám során, és nekem célom volt az, hogy olyanná váljak, mint ök. Én mindig erre törekszem, és amikor a visszajelzésben látom azt, hogy visszajönnek azok az értékek, azok a jellemzök, amik ott nekem mintaként szolgáltak, nekem ez számít (3. eset 5.).

Egy pedagógusnál nagyon érezhető volt a bizonytalanság a saját elvárásaival kapcsolatban.

Ez optimális esetben felülröl is, meg... itt érzek egy kis ..... már kormányzati szinten ... tehát nem iskola szinten, hanem úgy az oktatási rendszer oldaláról. Még olyan konfúz az egész. Nem mindig érzem, hogy akkor kell a kompetencia, vagy nem kell, hogy hogy, vagy mint ... (8. eset 23.)

Egy pedagógusnál pedig inkább a különböző befolyásoló tényezők hatása volt nagyon érezhető, az alábbi idézet a diákok szüleinek hatását támasztja alá.

Mind a kettö nagyon fontos. Nyilván a kis életüket, a pályájukat, nagyon fontos, hogy a tudásuk gyarapodjon. Emberi, értékrendbeli, meg az, hogy egyfajta tudásvágy, egy önállóságra nevelést is szeretnék elérni. Komplex dolog ez. Prioritást egyértelmüen nem élvez... nyilván, hát azért vagyunk itt, az oktatásért, tehát ezt elörehelyezném, de semmiképpen sem az emberi vonatkozások hátrányára. Van olyan fiú az osztályomban, aki egyértelmüen nem való a gimnáziumba, és az édesanyja azt mondta, hogy ez a szociális közeg, társaság annyira inspiráló számára, hogy higgyem el, hogy meg fog komolyodni, és hogy ö ezt az ivet hagy járja be, adjunk neki idöt, tehát hogy egy gerinces nemes lelkü ember legyen belöle. Ez azért a családi háttéren is múlik (6. eset 8.). 
Az interjúalanyaink tehát nagyon különböztek egymástól, volt, akinek szilárd és koherens nézetei vannak saját pedagógusi identitására vonatkozóan, voltak, akik érezték a koherens nézetek fontosságát, de nem fogalmazták meg ezeket, és voltak, akik nem is érezték az identitásukra vonatkozó nézetek megfogalmazásának szükségességét. Mindebből azt a következtetést vontuk le, hogy a pedagógusok szakmai önértékelésre vonatkozó nézeteit a koherencia szempontjából az határozza meg, hogy milyen erősségü pedagógusidentitással rendelkezik. A hitvallás megfogalmazása az identitás erősségének a mutatója.

\section{A pedagógusok önértékelése és szakmai énhatékonysága}

Arra vonatkozóan, hogy a direkt megnyilatkozásokon kívül hogyan is értékelik a pedagógusok önmagukat a lekódolt szövegek elemzése révén kerestük a válaszokat. A szakmai önértékelés két alkódját hoztuk létre: pozitív és negatív szakmai önértékelés:

\begin{tabular}{|c|c|c|c|c|c|c|c|c|c|c|}
\hline Code System & 9 & 8 & 7 & 6 & 5 & 4 & 3 & 2 & 1 & SUM \\
\hline 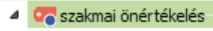 & ㅁ & 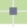 & $\square$ & $\square$ & 무 & " & & 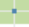 & & 21 \\
\hline$\circlearrowleft$ direkt negativ & & & - & $\cdot$ & - & & & & & 4 \\
\hline$\oplus_{\text {indirekt pozitiv }}$ & & & & & & & & & & 1 \\
\hline$\triangle$ indirekt negativ & 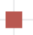 & 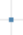 & - & - & & & & & & 7 \\
\hline$\odot$ önbizalom & $\mathbf{\square}$ & & & & & & & & & 3 \\
\hline$\odot$ direkt pozitiv & & - & - & घ & - & - & & - & & 9 \\
\hline$\sum$ SUM & 11 & 4 & 8 & 10 & 6 & 4 & 0 & 2 & 0 & 45 \\
\hline
\end{tabular}

4. ábra. A szakmai önértékelés alkódjai

A kódolás során azonban további alkódok kialakítására volt szükség. Voltak, akik csak a pozitív szakmai önértékelést (2. eset) fejezték ki direkt módon, voltak olyanok, akik direkten és indirekten is (4. eset) megfogalmazták azt (4. ábra). Mások a negatív szakmai önértékelést fejezték ki direkt módon, vegyítve indirekt negatívval és kompenzálva direkt pozitívval (7. 6. estek), vagy fordítva: direkt pozitív indirekt negatívval (8. eset). Két pedagógus nem válaszolt a szakmai önértékelést firtató kérdésre (1. és 3. esetek). Egy esetben indirekt módon fogalmazta meg a válaszadó negatív (9. eset) szakmai önértékelését, itt a jelzés nagysága a többszöri megemlítést jelenti, és végül az 5. esetnél igen szélsőségesen direkt pozitív és direkt negatív módon is kifejtette a pedagógus az önértékelését. 


\section{Code Co-Occurrence Model}

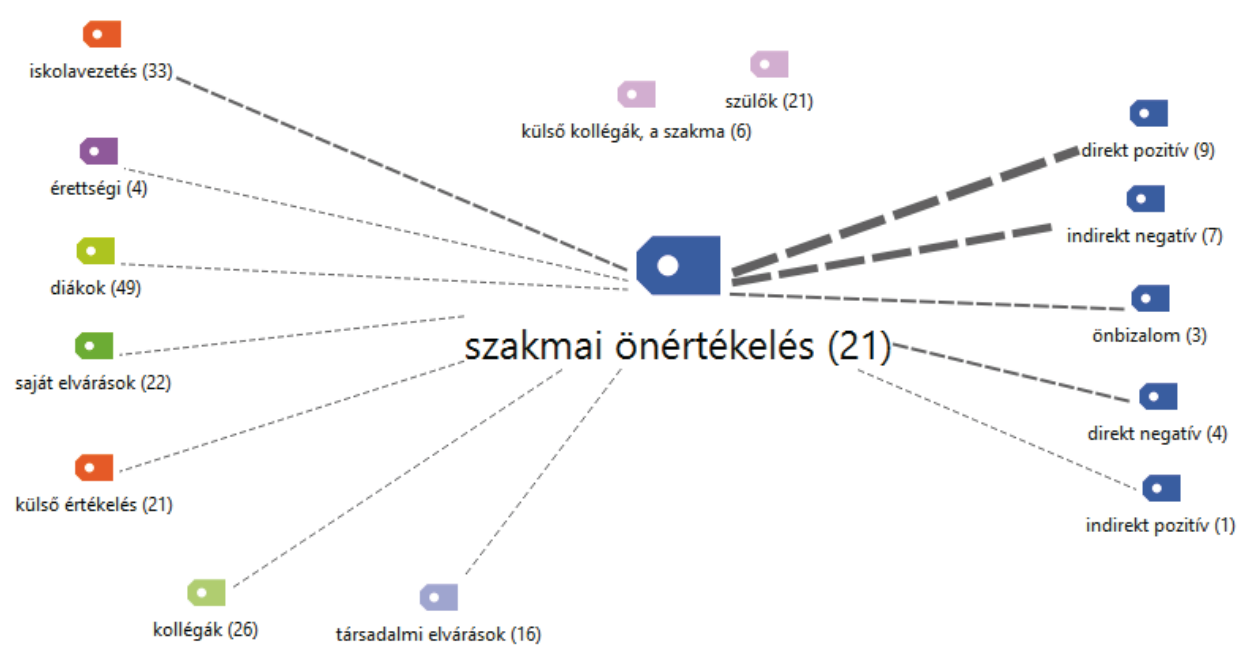

5. ábra. A szakmai önértékelés és az elvárások összefüggései

Érdemesnek tartottuk megvizsgálni, hogy a szakmai önértékelés és az elvárások milyen erősségű kapcsolatban vannak egymással (5. ábra). A szakmai önértékelés esetében a két legjellemzőbb forma a direkt pozitív és az indirekt negatív önértékelés volt. Az önbizalom, valamint a direkt negatív és indirekt pozitív önértékelés már kevésbé erősen voltak jelen az önértékelésben. A másik oldalon az elvárások és a szakmai önértékelés kapcsolata rajzolódott ki előttünk. Elsősorban az iskolavezetés elvárásai mutattak erős kapcsolatot a szakmai önértékeléssel. Érdekesség, hogy a kvantitatív szakaszban olyannyira fontosnak tartott saját elvárások, de akár a diákok elvárásai itt gyengébb hangsúllyal jelentek meg. Ennek okát abban láttuk, hogy a strukturált interjú, mint módszer talán több lehetőséget adott a pedagógusoknak annak kifejtésére, hogy a mindennapi életben a különböző elvárásokat hogyan rangsorolják, másrészt elgondolkodtató lehet az oktatás centralizációjának a vezetőkőn keresztül ily módon érvényesülő indirekt hatása.

Azt is megnéztük, hogy a szakmai önértékelés és a különböző elvárások pontosan mely területeken kapcsolódtak egymáshoz: 


\begin{tabular}{|l|c|c|c|c|}
\hline \multicolumn{1}{|c|}{ Code System } & $\begin{array}{c}\text { direkt } \\
\text { negatív }\end{array}$ & $\begin{array}{c}\text { indirekt } \\
\text { pozitív }\end{array}$ & $\begin{array}{c}\text { indirekt } \\
\text { negatív }\end{array}$ & $\begin{array}{c}\text { direkt } \\
\text { pozitív }\end{array}$ \\
\hline elvárásoklkülső kollégák, a szakma & 0 & 0 & 0 & 0 \\
\hline elvárásoklszülók & 0 & 0 & 0 & 0 \\
\hline elvárásoklérettségi & 0 & 0 & $\mathbf{1}$ & 0 \\
\hline elvárásokliskolavezetés & $\mathbf{1}$ & 0 & $\mathbf{2}$ & 0 \\
\hline elvárásokltársadalmi elvárások & 0 & 0 & $\mathbf{2}$ & 0 \\
\hline elvárásoklkülső́rtékelés & 0 & $\mathbf{1}$ & 0 & 0 \\
\hline elvárásokldiákok & $\mathbf{1}$ & 0 & 0 & $\mathbf{1}$ \\
\hline elvárásoklsaját elvárások & 0 & 0 & 0 & $\mathbf{1}$ \\
\hline elvárásoklkollégák & $\mathbf{1}$ & 0 & 0 & 0 \\
\hline
\end{tabular}

3. táblázat. Kódok együttjárása a szakmai önértékelés és az elvárások vonatkozásában

Direkt módon a pozitív szakmai önértékelés a diákok és a saját elvárások vonatkozásában jelent meg (3. táblázat). Indirekt pozitív hatást gyakorolt a külső értékelés. Direkt negatív szakmai önértékelés jelent meg az iskolavezetéssel, a diákokkal és a kollégákkal kapcsolatban, indirekt negatív pedig az érettségivel, az iskolavezetéssel és a társadalmi elvárásokkal kapcsolatosan. A szülőkkel és a külső kollégákkal kapcsolatban nem jelentek meg kapcsolatok a szakmai önértékelés vonatkozásában, vagyis a pedagógusok megemlítették ezeket a forrásokat, mint elvárásokat, hogy fontosak számukra, de hogy ezek mennyiben befolyásolják őket az önértékelésben, azt nem fogalmazták meg. 


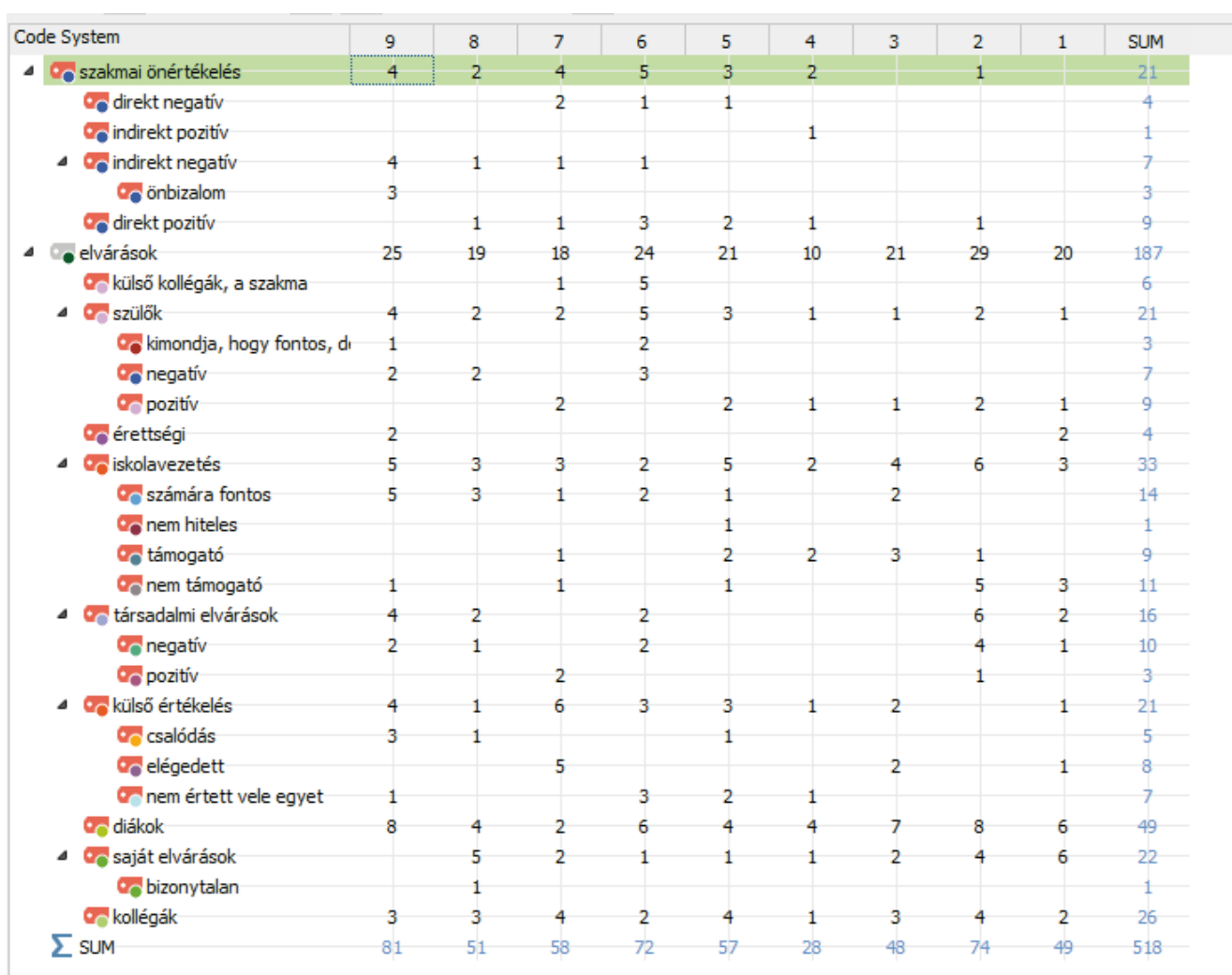

6. ábra. A szakmai önértékelés és a szakmai énhatékonyság összes alkódjának megjelenése a kilenc interjúalanynál

Mindezek után kézenfekvő volt a kérdés, hogy lehet-e csoportosítani a harmadik kutatási szakasz interjúalanyait. A csoportosítást a fókódok és azok alkódjainak elemzése alapján végeztük el (6. ábra). Két esetben csak indirekt módon további alkódok voltak segítségünkre az önértékelés meghatározásához. A többi esetben az önértékelés direkt/indirekt kódjainak arányából határoztuk meg azt, hogy pozitív, vagyis magas, vagy negatív, azaz alacsony a válaszadó szakmai önértékelése. A másik dimenziót a kolléga-igazgató, valamint a diákok és szüleik jelentették, mint a szakmai énhatékonyság forrásai. 


\begin{tabular}{|c|c|l|}
\hline esetek & szakmai önértékelés & \multicolumn{1}{|c|}{ személyes énhatékonyság legfőbb forrása } \\
\hline 1. eset & negatív (alkódok alapján) & $\begin{array}{l}\text { saját elvárások (10), diákok (6), iskolavezetés (3), kollégák } \\
\text { (2), külső értékelés (1), szülők (1) }\end{array}$ \\
\hline 2. eset & pozitív & $\begin{array}{l}\text { társadalmi elvárások (11), saját elvárások (9), diákok (8), } \\
\text { iskolavezetés (6), kollégák (4), szülők (2) }\end{array}$ \\
\hline 3. eset & pozitív (alkódok alapján) & $\begin{array}{l}\text { diákok (7), saját elvárások (6), iskolavezetés (4), külső } \\
\text { értékelés (2), kollégák (3), szülők (1) }\end{array}$ \\
\hline 4. eset & pozitív & $\begin{array}{l}\text { diákok (4), iskolavezetés (2), külső értékelés (1), kollégák } \\
\text { (1), szülők (1), saját elvárások (1) }\end{array}$ \\
\hline 5. eset & negatív & $\begin{array}{l}\text { iskolavezetés (5), diákok (4), kollégák (4), saját elvárások } \\
\text { (3), külső értékelés (3), szülők (3) }\end{array}$ \\
\hline 6. eset & pozitív & $\begin{array}{l}\text { diákok (6), szülők (5), külső értékelés (3), iskolavezetés (2), } \\
\text { kollégák (2), saját elvárások (2) }\end{array}$ \\
\hline 7. eset & negatív & $\begin{array}{l}\text { külső értékelés (6), kollégák (4), saját elvárások (4), iskol- } \\
\text { avezetés (3), diákok (2), szülők (2) }\end{array}$ \\
\hline 8. eset & pozitív & $\begin{array}{l}\text { saját elvárások (8), diákok (4), iskolavezetés (3), kollégák } \\
\text { (3), szülők (2), külsó értékelés (1), }\end{array}$ \\
\hline 9. eset & negatív & $\begin{array}{l}\text { diákok (8), iskolavezetés (5), külső értékelés (4), szülők (4), } \\
\text { kollégák (3) }\end{array}$ \\
\hline
\end{tabular}

4. táblázat. A minta elemeinek besorolása a kvantitativ kutatás elméleti modelljébe

A szakmai énhatékonyság forrásainál a mellettük megnevezett számok voltak a mérvadók. Ezeket összeadtuk, és így határoztuk meg, hogy az adott interjúalanynál a diákok és szüleik vagy a kolléga és az igazgató elvárásai voltak-e a dominánsabbak. Mindezek alapján tehát a válaszadók közül 2 pedagógus (1. és 9. eset) volt sorolható az alacsony szakmai önértékelésủ és diák (szülö)-orientált kategóriába, 2 fó (5. és 7. esetek) az alacsony szakmai önértékelésű és kolléga-igazgató orientált kategóriába, 4 pedagógus a magas szakmai önértékelésű, kolléga-igazgató orientált csoportba (2., 3., 4. és 8. esetek) (4. táblázat). Egy pedagógus (6. eset) magas szakmai önértékeléssel rendelkezik, de nála a külső értékelés igen erősen orientáló hatással bírt. Mivel kutatásunk előző szakaszának egyik következtetése szerint (Zagyváné, 2019) a külső értékelésben részt vett pedagógusok a diákokkal végzett munka értékeléseként tartják számon a külső értékelés eredményét, így a 6. esetben a diákok, szülők és a külső értékelés említésének számait összeadtuk. Ennek alapján tehát a 6 . interjúalanyunkat a magas szakmai önértékeléssel bíró, de diák (szülö) orientált csoportba soroltuk.

A 4. interjúalany az előző kutatási szakaszban az alacsony szakmai önértékelésűek között szerepelt, a kvalitatív tartalomelemzés szerint azonban pozitív/magas a szakmai önértékelése. A 4. interjúalanyunk saját maga adott választ erre az anomáliára, kiemelve 
maximalizmusát, ugyanakkor rávilágítva arra a dilemmára, hogy mindig 100\%-osnak értékelhetjük-e magunkat, illetve egyáltalán értékelhetjük-e magunkat 100\%-ra:

A minösitési eljárásban szerzett eredményemnek csak egy szegmensével nem voltam elégedett. Az önképzésre való törekvésre nem kaptam 100\%-ot. Akinek több végzettsége van, mint nekem, az szerintem festi magát, de mindegy. Az önértékelési kérdöivet, ahogy kitöltöttük, mert most a belsö önértékelési rendszerben én már benne voltam. És akkor mondta az igazgatóhelyettes, hogy én nagyon-nagyon kritikus voltam magammal, bezzeg a többiek nem ennyire. Tudom, hogy én kritikus vagyok, de igy sem volt 100\%-ban reális. Nem mondja senki, hogy mindig a tantervi követelményekkel ö 5-ös. Nem létezik, mindig kell frissiteni. Úgyhogy mondtam neki, hogy lehettem volna kritikusabb, tehát az úgy jó volt. Ez jelenti, hogy maximalista vagyok. Mindig úgy voltam, hogy ha valamit meg kell csinálni, azt maximálisan csinálom, nálam az ilyen köztes dolgok nem müködnek. (4. eset 25.)

\begin{tabular}{|c|c|}
\hline $\begin{array}{c}\text { magas szakmai önértékelés, kolléga- szülö-igaz- } \\
\text { gató orientáltság } \\
(2 ., \text { 3., és } 8 \text {. esetek) }\end{array}$ & $\begin{array}{c}\text { alacsony szakmai önértékelés, kolléga- szülö-igaz- } \\
\text { gató orientáltság } \\
\text { (5. és 7. estek) }\end{array}$ \\
\hline $\begin{array}{c}\text { magas szakmai önértékelés, diákorientáltság } \\
\text { (6. és 4. eset!) }\end{array}$ & $\begin{array}{c}\text { alacsony szakmai önértékelés, diákorientáltság } \\
\text { (1. és 9. esetek) }\end{array}$ \\
\hline
\end{tabular}

\section{7. ábra. Az interjúalanyok besorolása a szakmai önértékelés} és a szakmai énhatékonyság észlelése alapján

Elemzésünk eredményeként egy igen változatos mintázat rajzolódott ki előttünk két dimenzió mentén (7. ábra). Az egyik a magas/pozitív és alacsony/negatív önértékeléssel bíró pedagógusok köre, a másik a diákok és szüleik visszajelzéseit előtérbe helyező, valamint a vezetők és kollégák visszajelzéseit előtérbe helyezők köre. Érdekesség, hogy a saját elvárások elsődlegessége két pedagógusnál jelent meg (1. eset és 8. eset), az egyik alacsony/negatív, a másik magas/pozitív szakmai önértékeléssel bír.

\section{A külsö értékelés és a szakmai önértékelés eltérése}

A kutatásunk egyik kérdése volt, hogy ha a pedagógus külső értékelése és a saját önértékelése között eltérés mutatható ki, akkor mi lehet ennek az oka. Reális szakmai önértékelés esetében a külső értékelés eredményével való elégedettség valósul meg. Az előző kutatási szakaszban elemzésünkben rámutattunk egy speciális csoportra, azaz a külső értékelés eredményével nem elégedettekre. Jól látható volt, hogy a 71 nem elégedett pedagógus között voltak olyanok, akik a legjobb eredményeket érték el, mégsem voltak elégedettek. Kutatásunk ezen szakasza további lehetőségeket biztosított számunkra, hogy ezt a kérdéskört alaposabban megvizsgáljuk. Egyrészt az interjúk, másrészt a gondolattérképek alapján kívántuk tisztázni ezt a kérdéskört. 
Az interjúk főkódjai között az elvárásoknál külön alkódban volt megjeleníthető a külsö értékelés, ami itt egyértelműen a minősítő vizsgát vagy eljárást jelentette.

\section{One-Code Model}

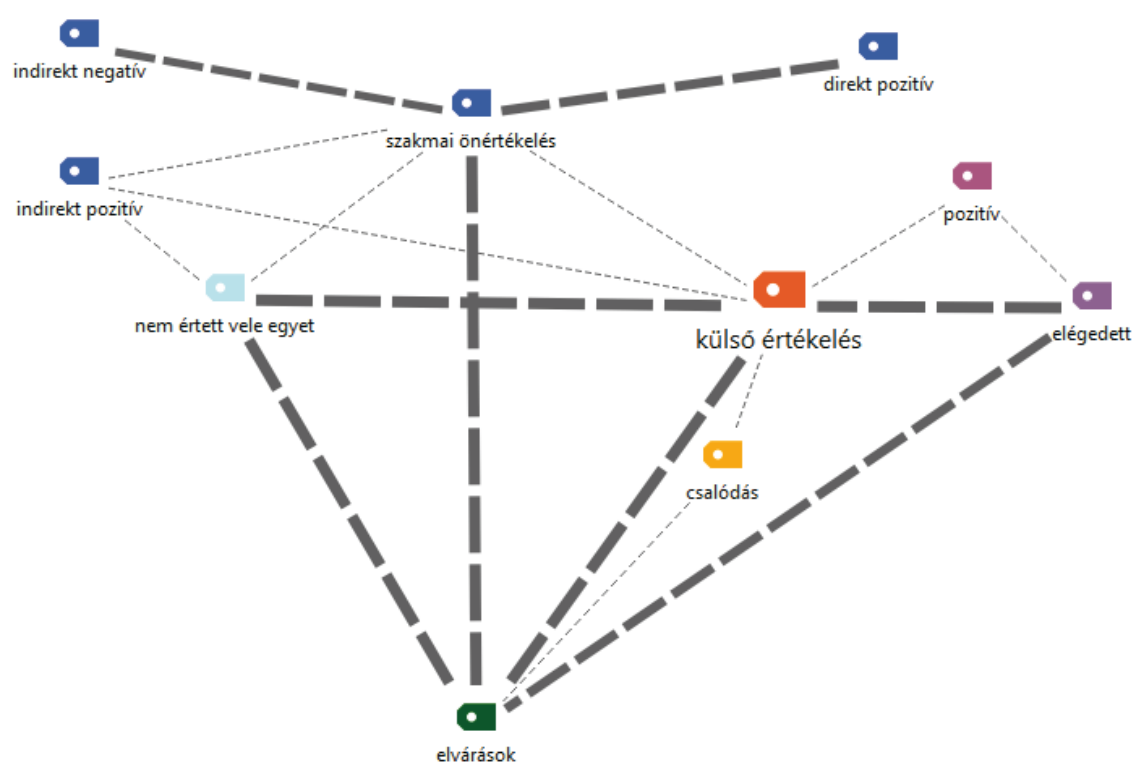

8. ábra. A külsö értékelés kapcsolatai

A 8. ábrán jól látható, hogy a külső értékelés a pedagógusok szakmai önértékelésében mint elvárás kimutatható volt, de nem tulajdonítottak neki kimagasló szerepet. Inkább indirekt hatást gyakorolt a szakmai önértékelésre a külső értékelés eredménye. Ennek három alkódját alakítottuk ki: az elégedett, nem elégedett vele és a csalódás. Az elégedettek (1., 3., és 7. esetek) szakmai hitelességük visszaigazolását kapták meg a külső értékelés segítségével.

Elfogadták, tehát, hogy ez pedagógiai és irodalmi tevékenységet jelent, és kellö súllyal értékelték. Semmilyen kritika nem ért, és nem mondtak olyat, ami hiányzott volna (1. eset 12).

Nekem életem egyik legszebb napja volt. Mert fontos számomra, hogy azokat az értékeket meglássák a munkámban, amiket a nagy öseimtöl, a tanáraimtól, a gimis tanáraimtól szerettem volna átvenni, és amikor ezt a szemembe mondják azon két óra alapján, meg amit leirtam a portfoliómban, ennél nagyobb öröm szerintem kevés van egy tanár számára. Tehát nekem nagyon jó érzés volt (3. eset 21). 
Én nagyon elégedett vagyok vele, és én vágytam már erre, hogy valaki azt mondja, hogy jól csinálod. Most lehet, hogy nagyképűségnek tűnik, de ez nagyon fontos. Én erre vágytam, és ami érdekes volt, hogy a szakmaiságom, vagyis a nyolcas kompetenciában 100\%-ot hoztak ki. Hát majdnem szembe röhögtem magam, mert akkor én már gondolkoztam azon, hogy már most befejezem ezt az egészet, mert már nem érdekel. És annak ellenére, amit leírtam, meg előadtam magam, ők nem ezt látták (7. eset 18).

A 7. interjúalany már a pálya elhagyásán gondolkozott, amikor a minősítési eljáráson részt vett. Különös, hogy éppen egy külső értékelés térítette vissza, és győzte meg arról, hogy a pályán a helye. Elkeseredésének oka az előző munkahelyén a vezetői és a kollégái érdektelensége volt. Munkahelyet váltott, azóta már jól érzi magát a pályán.

Nekem ez a minösités volt, hogy azt mondtam, hogy jó, nekem innen (elöző munkahely) mennem kell. Amit nekem a minösitésen elmondtak, hogy akkor döbbentem rá, hogy nekem, ha ez a minösités nem lett volna, akkor rég itt hagyom a pályát. Tehát nem lett volna... úgy leépül az ember, hogy soha senki nem értékeli a munkádat (7. eset 14).

Akik nem voltak elégedettek (4., 6. és 9. esetek), azok kételyeiket a külső értékelés hitelességével kapcsolatosan fogalmazták meg.

A minösitési eljárásban szerzett eredményemnek csak egy szegmensével nem voltam elégedett. Az önképzésre való törekvésre nem kaptam 100\%-ot. Akinek több végzettsége van, mint nekem, az szerintem festi magát, de mindegy (4. eset 24.).

Nyilván nekem is volt, ahol megkérdöjeleztem, nyilván nem firtattam ezt. Válaszoltam az ott feltett kérdésekre a védés folyamán. Voltak kérdöjelek nyilván, de most nem azt mondom, hogy annyiban maradt, de én elfogadtam. Egy külsö szakmai bizottság 3-4 föböl az elmondottak alapján így vélekedik, akkor én azt elfogadtam. Nyilván másképp látja az ember önmaga, a saját szempontjából (6. eset 38).

Nyilván számit, hiszen voltak benne belsö kollégák és külsö kolléganö, nagyon szimpatikus, kedvesen elbeszélgettünk, csakhogy egymás munkáját, hogy is lehetne jogunk százalékolni egy pároldalas portfolió alapján, azt nem tudom. Erröl lehetne sokat beszélgetni (6. eset 40.).

Énnekem csak egy kicsit az motoszkál a fejemben, hogy amikor elkezdődött az értékelés, mindenki az első körben 100\%-ot kapott, ami amúgy teljesen lehetetlen, mert olyan ember nincs. És egyszer, valamikor előhalásszák ezt, amikor valakinek a munkáját minősítjük, vagy rangsorba állítjuk, akkor első körben mindenki szuper volt, a másodikban már mindenki kezd reálisabban értékelni, és akkor ez háttérbe szorítja azokat, akiket később értékeltek. No, nem megyek ettől a pataknak, de ez olyan furcsa (9. eset 34.)

A külső értékelés eredményével elégedetleneket abból a szempontból is megvizsgáltuk, hogy a saját elvárásaik mennyire kaptak explicit kifejezést. A három nem elégedett pedagógus esetében közös vonás volt, hogy a saját elvárások kevesebbszer (4. és 6. eset) vagy egyáltalán nem (9. eset) jelentek meg (lásd 4. táblázat), mint bármely más elvárások. 


\begin{tabular}{|l|l|}
\hline a szakmai önértékelés & esetek \\
\hline pozitív, magas szakmai önértékelésűek & 4. és 6. esetek \\
\hline negatív, alacsony szakmai önértékelésủek & 9. eset \\
\hline
\end{tabular}

5. táblázat. A nem elégedettek szakmai önértékelése

A nem elégedett interjúalanyaink tehát kvalitatív eredményeink alapján is besorolhatók abba a csoportosításba, amelyet a kutatás előző szakaszának 71 nem elégedett pedagógusára alakítottunk ki. A két pozitív vagy magas szakmai önértékelésű tanár közül az egyik a diákok és szüleik, a másik a kollégák-igazgató elvárásait tartja mérvadónak önmaga számára (5. táblázat). Az egy negatív vagy alacsony szakmai önértékelésű pedagógus a diákok (szülők) elvárásait tartja elsődlegesnek. Mindhárman a minősítés hitelességet kérdőjelezték meg: egy tartalmi vonatkozásból (4. eset), kettő pedig mérésmódszertani szempontból (6. és 9. eset).

A minösitési eljárásban szerzett eredményemnek csak egy szegmensével nem voltam elégedett. Az önképzésre való törekvésre nem kaptam 100\%-ot. Akinek több végzettsége van, mint nekem, az szerintem festi magát, de mindegy (4. eset 24).

...... én persze nem hiszem, hogy a pedagóguslét ennyire számszerüsithetölehet. (6. eset 38).

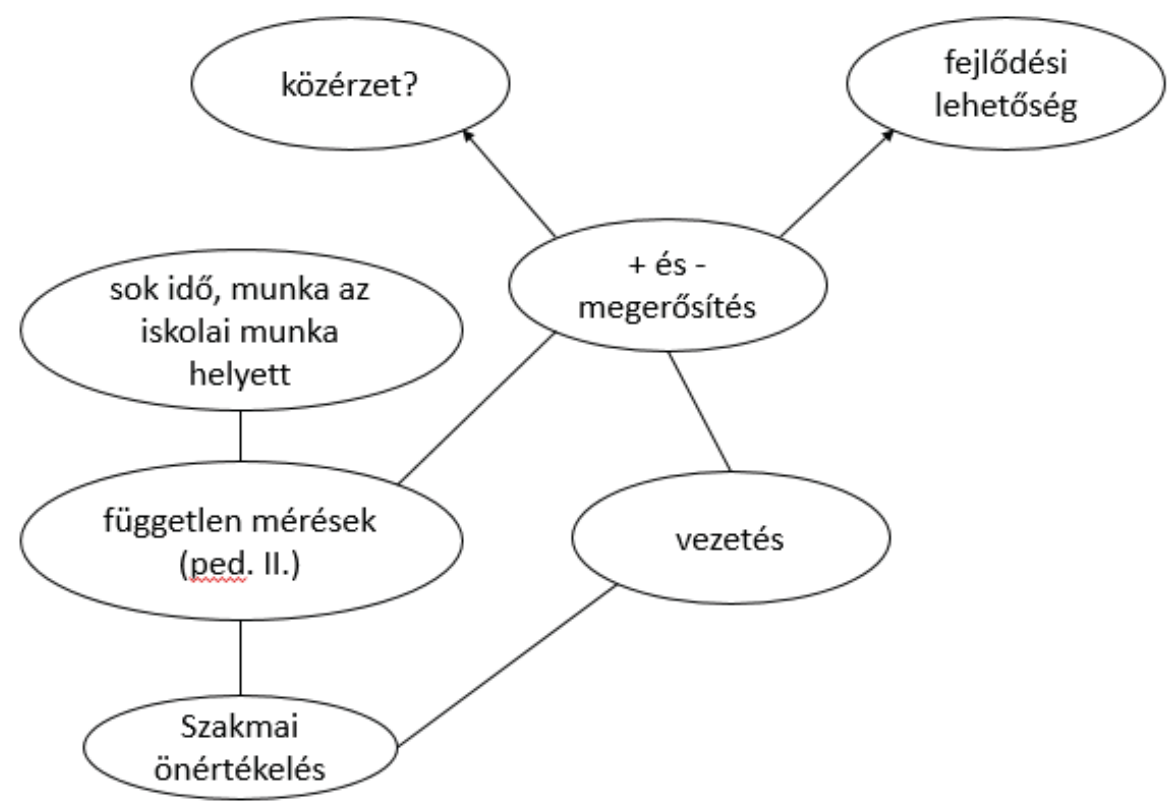

9. ábra. Gondolattérkép részlet-külsö értékelés (9. eset)

(Az interjualany saját készitésü gondolattérképe alapján) 
Énnekem csak egy kicsit az motoszkál a fejemben, hogy amikor elkezdődött az értékelés, mindenki az első körben 100\%-ot kapott, ami amúgy teljesen lehetetlen, mert olyan ember nincs. És egyszer, valamikor előhalásszák ezt, amikor valakinek a munkáját minősítjük vagy rangsorba állítjuk, akkor első körben mindenki szuper volt, a másodikban már mindenki kezd reálisabban értékelni, és akkor ez háttérbe szorítja azokat, akiket később értékeltek. No nem megyek ettől a pataknak, de ez olyan furcsa (9. eset 34) (9. ábra).

Kutatásunkban a beágyazott kutatás ezt megelőző szakaszának mintájából kiválasztott pedagógusok nézeteit elemeztük. Eredményeink alapján kijelenthető, hogy a környezet, vagyis a tanítás kontextusa befolyásolja a pedagógusok szakmai önértékelését, pontosabban az általuk előnyben részesített elvárások körét, amelyhez viszonyítják eredményeiket. A kontextus összetevői az iskolatípus, azon belül az évfolyam, a tagozat, a pedagógus által tanított tantárgy, a gyerekek tudásszintje, neveltségi szintje és családi háttere.

Egy árnyalt kép rajzolódott ki elöttünk, és az árnyalatok egyik körét a szakmai önértékelés direkt vagy indirekt megjelenési formái adták. A másik körben a szakmai énhatékonyság észlelésének forrásai jelentek meg plasztikusan. Jól elkülöníthetők voltak a saját elvárások, a diákok, a szülők, kollégák, iskolavezetők, a külső értékelés, és néhol még a tágabb szakmai és társadalmi közeg elvárásai is kimutathatók voltak. Az elvárások sajátos együttjárása volt kimutatható: diákok-szülők, kollégák-vezetők, külső értékelés-diákok. Számunkra meglepő eredmény, hogy bár a pedagógusok saját elvárásaiknak és azon belül az általuk fontosnak tartott személyiségtulajdonságoknak kívánnak megfelelni, ebben a mintában mégis nagyon meghatározó volt a vezetők elvárásainak való megfelelési igény. Mindez a szakmai önértékelésben a vezetők felelősségteljes szerepének tudatosítását veti fel. A kvalitatív tartalomelemzés alapján elmondhatjuk, hogy a külső értékelés elvárásainak való megfelelés igénye inkább közvetve jelenik meg a pedagógusok szakmai önértékelésében. A külső értékelés, azaz a minősítés mind pozitív, mind negatív kontextusban jelen van a pedagógusok nézeteiben. Pozitív hozadéka a megerősítés, tudatosítás, a szakmai hitelesség alátámasztása, bizonyos esetekben kompenzáció a vezetés vagy kollégák visszacsatolásának elmaradása miatt. Negatív hozadékai a túl sok idő- és energiabefektetés, amelynek nincs meg a megfelelő kompenzációja, valamint a tartalmi és módszertani érvényesség vonatkozásában felmerülő hiányérzet. A külső szakmai értékelés és a szakmai önértékelés eltérésének tehát létezik egy külső, magából az értékelési rendszerből származó oka. Ugyanakkor van egy másik, belső ok is, ez pedig, hogy a saját elvárások nem, vagy csak kevésbé élveznek prioritást a pedagógus nézetrendszerében, vagyis ha a reális önértékelést mint fejlesztési célt határozzuk meg, akkor a saját elvárások felszínre hozatala, tudatosítása kell, hogy a kiindulópont legyen. 


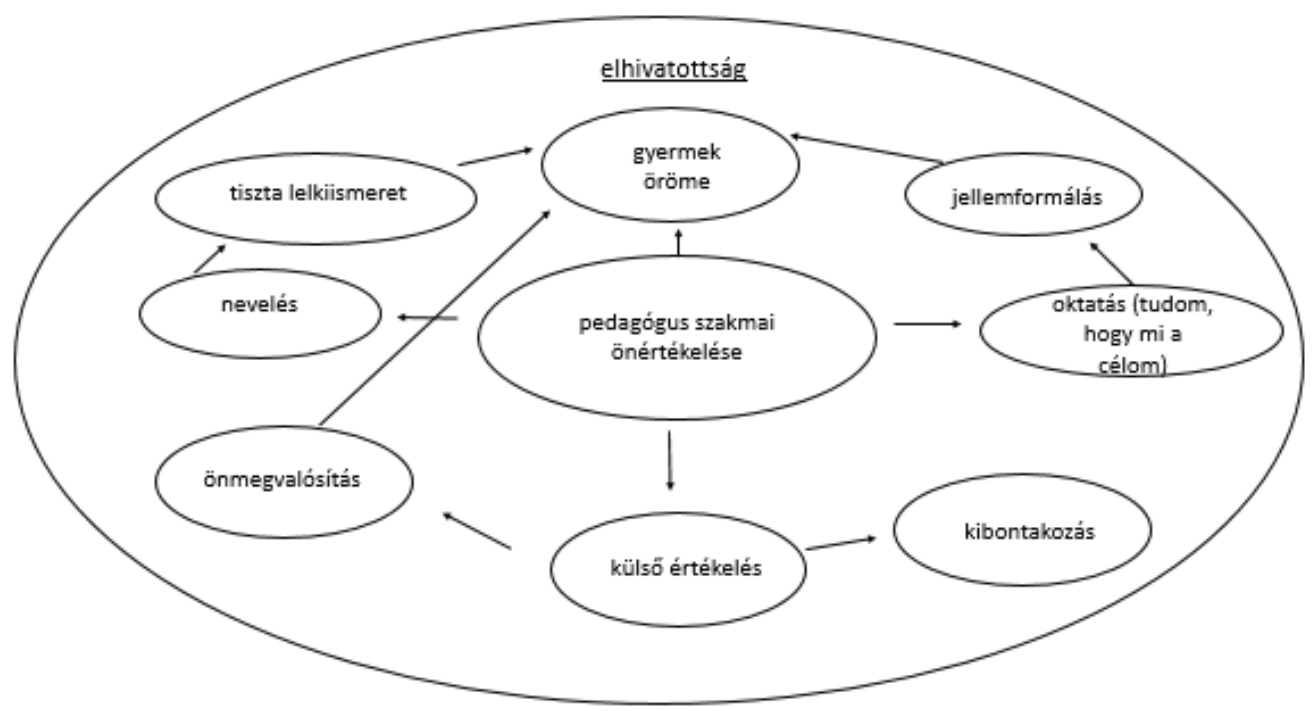

10. ábra. Gondolattérkép-hitvallás-saját elvárások (1. eset)

(Az interjualany saját készitésü gondolattérképe alapján)

A saját elvárások vizsgálata révén a szakmai önértékelésre vonatkozó nézetek koherenciájának a kérdésére is választ kaptunk. A saját elvárások többszöri kifejezésére az 1., 2 ., 3., 7. és 8. esteknél került sor (lásd 4. táblázat). Közülük a saját pedagógusi hitvallásukat az 1. (10. ábra) 2. 3. és 7. interjúalanyok fejtették ki, és ők mindannyian elégedettek a külső értékelésük eredményével. Az 1. interjúalany szilárd belső értékrendeje, pedagógusképe a következő hitvallásban rajzolódott ki.

... ez egy elhivatottságból fakadó pálya, és csak úgy lehet végezni, ha az ember nem is emberi véleményekre ad, hanem azt képzeli el, hogy végül is a Jó Isten mit szólna ahhoz a tevékenységhez, amit mi az egész életünkön át végzünk. És hogy ha én magabiztossággal és tiszta lelkiismerettel tekintek végül is az Istennek a szemébe, akkor azt mondhatom, hogy megtettem mindent az embertársaimért, a diákjaimért, kollégáimért, az irodalomért. Fenntartottam azokat az értékeket, amiket én a tanitásom során a müvészeti alkotásokban találkozom. Tehát fenntartottam azt, hogy emberségesnek lenni, mindig szeretni. Végül is minden irodalmi mü arról szól, hogy a szeretethiány milyen rombolást végez az emberi lélekben. Gondoljunk József Attilára vagy az összes többi költöre. A szeretet az egyszerüen kulcskérdés. És a másik, hogy a tanulóimat lelkiismeretes tanulásra szeretném birni. Illetve tudja azt, hogy a helye hol van a világban... (1. eset 16.).

A hitvallás szerepe olyannyira fontos számára, hogy ez segíti őt szakmai feladatai végrehajtásában. Hisz benne, hogy amit pedagógusként tesz, az minőségi szakmai munka. Ez a pozitív hit szerinte átsugárzott a minősítési eljárás során is. Ezzel magyarázható, 
hogy a kvantitatív szakasz eredményeinek látszatra ellentmondóan a szakmai önértékelés erőteljesebb hatását láttuk kibontakozni a külső értékelésre vonatkozóan. Valójában interjúalanyunk „átvitte” hitvallását a bizottságnak. Az eljárásról így vélekedett:

Nem soroltak fel hiányosságot. Elfogadták, ez pedagógia és irodalmi tevékenységet jelent és kellö súllyal értékelték. Semmilyen kritika nem ért és nem mondtak olyat, ami hiányzott volna (1. eset. 12).

Lehet valaki alacsony vagy magas szakmai önértékeléssel rendelkezö, és származhatnak szakmai énhatékonyságának forrásai akár a diákoktól, akár a kollégáktól, szülőktől, vezetőktől, külső értékelés eredményéből vagy más tényezőktől; a saját elvárások építik fel identitását, és azok belső szerkezete pedagógus nézeteinek koherenciáját, legyen szó akár pedagógus szakmai önértékelésről, akár bármilyen más szakmai kérdésről.

\section{Összegzés}

Kvalitatív vizsgálatunk során három kérdésre kerestük a választ. Az első kérdéskör arra vonatkozott, hogy a pedagógus szakmai önértékelése során figyelembe vett elvárásokat milyen mértékben határozza meg az a kontextus, amelyben dolgozik. Egyértelmü bizonyítást nyert, hogy a szakmai környezet meghatározó szerepe. A szakmai környezet maga is egy összetett fogalom, amelyen belül az iskolatípus, ahol a pedagógus dolgozik, azon belül a tanított évfolyamok, a diákok tudásszintje, a tanított szaktárgy és a diákok neveltségi szintje, amely összefügg szociokulturális hátterükkel, mind nagyon befolyásoló tényezők.

A második kérdéskör az énhatékonyság észlelésének forrásaira vonatkozott. Eredményeink alapján elmondhatjuk, hogy sajátos mintázatok rajzolódtak ki a válaszadó pedagógusok esetében. Elkülönülnek egymástól a saját elvárások, a diákok, szüleik, a kollégák és a vezetők elvárásai és ezek mintázatai három nagyobb pólus mentén rajzolódnak ki: diákok és szüleik, vezetők és kollégák, valamint külső értékelés-diákok.

Harmadik kérdésünkkel arra kerestük a választ, hogy mi lehet az oka annak, ha a pedagógusok szakmai önértékelése és a külső értékelés között eltérés adódik. Két okot is sikerült beazonosítanunk. Az egyik a külső értékelési rendszerben (minősítés) keresendő, nem tartják megbízhatónak az értékelést a pedagógusok, a másik ok pedig a saját elvárásaikkal nincsenek kellő mértékben tisztában. Ebből következően két megoldandó feladatot fogalmazhatunk meg. Az egyik a külső értékelés elvárásainak közelítése a pedagógusok elvárásaihoz, a másik pedig az önismeret fejlesztése, saját elvárások tudatosítása. Javaslatainkkal egyrészt az életpályamodell továbbfejlesztését, másrészt pedig a pedagógusok önértékelési kompetenciáinak fejlesztését célozzuk meg. 


\section{Felhasznált irodalom:}

Athanasou, J. A. (2005): Self-evaluations in adult education and training. Australian Journal of Adult Learning, 3/45, 291-303. Letöltés dátuma: 2018. január 12, forrás: http://files.eric.ed.gov/fulltext/EJ797616.pdf

Bandura, A. (1977): Self-efficacy: Toward a Unifying Theory of Behavioral Change. Psychological Review, 84, 2, 191-215. Letöltés dátuma: 2018. március 10, forrás: https:// www.uky.edu/-eushe2/Bandura/Bandura1977PR.pdf https://doi.org/10.1037/0033-295X.84.2.191

Bandura, A. (1986): Social foundations of thought and action: A social cognitive theory. Englewood Cliffs, Prentice-Hall, Inc., NJ.

Bandura, A. (1997): Self-efficacy: The exercise of control. Freeman, New York.

Bandura, A. (2001): Social cognitive theory: An agentic perspective. Annual Review of Psychology, 52, 1-26. https://doi.org/10.1146/annurev.psych.52.1.1

Boekaerts, M. (2011): Emotions, emotion regulation, and self-regulation of learning. In: Zimmerman, B. J. és Schunk, D. H. (szerk.): Handbook of Self-Regulation of Learning and Performance. Routledge, New York, 408-425.

Caprara, G. V. (2002): Personality psychology: Filling the gap between basic processes and molar functioning,Vol 2. In: Hofsten, C., V.és L. Bakman, L. (szerk.): Psychology at the turn of the Millennium: Social, developmental and clinical perspectives. Psychology Press, EastSussex, UK, Vol 2, 201-224.

Caprara, G.V., Barbaranelli, C., Borgogni, L., Petitta, L. és Rubanacci, A. (2003a): Teachers', school staff's and parents' efficacy beliefs as determinants of attitudes toward school. European Journal of Psychology of Education, vol. XV111, n 1, 15-31. Letöltés dátuma:2018.03.10. forrás: http://www.uky.edu/ -eushe2/Pajares/CapraraEtAl2003. pdf https://doi.org/10.1007/BF03173601

Caprara, G., Barbaranelli, C., Borgogni, L. és Steca, P. (2003b): Efficacy Beliefs as Determinants of Teachers' Job Satisfaction. Journal of Educational Psychology, Vol 95, n 4, 821-832. https://doi.org/10.1037/0022-0663.95.4.821

Caprara, G. V., Barbaranelli, C. Steca, P. és Malone, P. S. (2006): Teachers' self-efficacy beliefs as determinants of job satisfaction and students' academic achievement: A study at the school level. Journal of School Psychology, 44. 473-490. Letöltés dátuma: 2018.05.06, forrás: https://www.sciencedirect.com/science/article/pii/ S0022440506000847 https://doi.org/10.1016/j.jsp.2006.09.001

Creswell, J. és Plano Clark, V. (2007): Designing and Conducting Mixed Methods Research. Thousand Oaks, Sage Publications. California. 
Efklides, A. (2011): Interactions of Metacognition With Motivation and Affect in SelfRegulated Learning: The MASRL Model. Educational Psychologist, 46(1), 6-25. Letöltés dátuma: 2018.06.12, forrás: http://www4.ncsu.edu/ -jlnietfe/Metacog_ Articles_files/Efklides\%20\%282011\%29.pdf https://doi.org/10.1080/00461520.2011.538645

Guskey, T. R. (2002): Professional Development and Teacher Change. Teachers and Teaching: theory and practice, 8,3/4, 381-391. Letöltés dátuma: 2018. 03. 03, forrás: http://www.tandfonline.com/doi/pdf/10.1080/135406002100000512 https://doi.org/10.1080/135406002100000512

Harris, A. és Brown, G.T. L. (2009): The complexity of teachers' conceptions of assessment: Tensions between the needs of schools and students. Assessment in Education: Principles, Policy and Practice, 16(3), 365-381. https://doi.org/10.1080/09695940903319745

Järvelä, S. és Hadwin, A. (2013): New frontiers: regulating learning in CSCL, Educational Psychology, 48(1), 25-39. https://doi.org/10.1080/00461520.2012.748006

MacGilchrist, B., Myers, K. és Reed J. (2004): Intelligens iskola. Paul Chapman Publishing Ltd. Letöltés dátuma: 2018. 04. 11, forrás: http://fszk.hu/images/stories/ Az_intelligens_iskola_-_6.fejezet_-_vgleges.pdf

Pintrich, P. R. (2000): The role of goal orientation in self-regulated learning. In: Boekaerts, M. és Pintrich, P.R. (szerk.): Handbook of self-regulation. Academic Press, CA, San Diego, 451-502. https://doi.org/10.1016/B978-012109890-2/50043-3

Sántha Kálmán (2009): Bevezetés a kvalitativ pedagógia kutatás módszertanába. Eötvös József Könyvkiadó, Budapest.

Winne, P. H. és Hadwin, A. F. (1998): Studying as self-regulated engagement in learning. In: Hacker, D. és Graesser, D. J. (szerk.): Metacognition in educational theory and practice. Hillsdale, Erlbaum, NJ. 277-304.

Yeung, A. S., Craven, R. G. és Kaur, G. (2014): Teachers' self-concept and valuing of learning: relations with teaching approaches and beliefs about students. Asia-Pacific Journal of Teacher Education, 42, 3, 305-320. Letöltés dátuma: 2018. 09. 07, forrás: https://doi.org/10.1080/1359866X.2014.905670

Zagyváné Szűcs Ida (2019): A pedagógusok szakmai önértékelését befolyásoló tényezők, különös tekintettel a külső szakmai elvárásokra és a szakmai énhatékonyság személyes észlelésére, Doktori értekezés, Eger, Letöltés dátuma 2021. január 7. forrás: http:// disszertacio.uni-eszterhazy.hu/73/1/\%C3\%89rtekez\%C3\%A9s.pdf

Zheng, H. (2009): A Review of Research on EFL Pre-Service Teachers' Beliefs and Practices. Journal of Cambridge Studies, 4, 73-80. Letöltés dátuma: 2018. 11. 11, forrás: https://www.repository.cam.ac.uk/bitstream/handle/1810/255675/200901article9.pdf?sequence $=1$ 
Zimmerman, B. J. (1995): Self-regulation involves more than metacognition: A social cognitive perspective. Educational Psychologist, 29. 217-221. https://doi.org/10.1207/s15326985ep3004_8

Zimmerman, B. J. (2000): Attaining self-regulation: A social cognitive perspective. In: Boekaerts, M., Pintrich, P.R. és Zeidner, M. (szerk.): Academic Press, San Diego, CA. 13-39. 